\title{
UJI AKTIVITAS ANTIOKSIDAN FRAKSI ETIL ASETAT, KLOROFORM, PETROLEUM ETER, DAN N-HEKSANA HASIL HIDROLISIS EKSTRAK METANOL MIKROALGA Chlorella sp.
}

\author{
Ony Novia Anggraeni, A. Ghanaim Fasya, Munirul Abidin, A. Hanapi
}

Jurusan Kimia, Fakultas Sains dan Teknologi, Universitas Islam Negeri Maulana Malik Ibrahim Malang

\begin{abstract}
Qur'an surah Luqman verse 10 says that God created plants that are beneficial to humans. Chlorella $s p$. was kind of microalgae that contains bioactive antioxidant components. Purpose of this research was to determine the antioxidant activity of fraction of ethyl acetate, chloroform, petroleum ether and n-hexane as results of hydrolysis of the methanol extract of microalgae Chlorella sp., and active compound of Chlorella $s p$. that identification by reagents test and thin layer chromatography (TLC).

Chlorella sp. was cultivated in Tauge Extract Medium (TEM) $4 \%$ and harvesting at $10^{\text {th }}$ day. Chlorella sp. macerated using methanol and hydrolyzed with $\mathrm{HCl} 2 \mathrm{~N}$ as catalyst. Furthermore, partitioned using the solvent: n-hexane, petroleum ether, chloroform, and ethyl acetate. Antioxidant activity was estimated by DPPH assay with spectrofotometry UV-Vis. Identification of the active compound groups conducted with test reagents and TLC.

The results showed that the $\mathrm{EC}_{50}$ value of methanol extract, the fraction of ethyl acetate, chloroform, petroleum ether, $\mathrm{n}$-hexane, and the aqueous phase as follows 1,$334 ; 332.7 ; 182 ; 27.26 ; 173.7$; and $1,411 \mathrm{ppm}$. The identification result of active compound showed that the extract of Chlorella $\mathrm{sp}$. containing steroids and ascorbic acid. Good eluents of TLC for steroids are hexane:acetone (7:3) and n-hexane:ethyl acetate (7:3). The best eluent for TLC for ascorbic acid is ethanol: $10 \%$ acetic acid $(9: 1)$.
\end{abstract}

Keywords: Chlorella sp., Hydrolysis, Antioxidant, DPPH, TLC

\section{ABSTRAK}

Al Qur'an surat Luqman ayat 10 menyebutkan bahwa Allah menciptakan tumbuh-tumbuhan yang bermanfaat bagi manusia. Chlorella sp. merupakan jenis mikroalga yang mengandung komponen bioaktif sebagai antioksidan. Tujuan dari penelitian ini adalah untuk mengetahui aktivitas antioksidan fraksi etil asetat, kloroform, petroleum eter dan n-heksana hasil hidrolisis ekstrak metanol mikroalga Chlorellasp., serta mengetahui golongan senyawa yang terdapat pada ekstrak mikroalga Chlorellasp. hasil identifikasi dari uji reagen dan kromatografi lapis tipis.

Chlorella sp. dikultivasi dalam MET $4 \%$ dan pemanenan dilakukan pada hari ke-10. Chlorella $s p$. dimaserasi menggunakan metanol dan dihidrolisis dengan katalis HCl 2N. Selanjutnya dipartisi menggunakan pelarut n-heksana, petroleum eter, kloroform, dan etil asetat.Uji aktivitas antioksidan dilakukan dengan metode DPPH secara spektrofotometri $U V$-Vis. Identifikasi golongan senyawa aktif dilakukan dengan uji reagen dan KLTA.

Hasil penelitian menunjukkan bahwa nilai $\mathrm{EC}_{50}$ ekstrak metanol Chlorella sp., fraksi etil asetat, kloroform, petroleum eter, n-heksana, danfasa air berturut-turut 1.334; 332,7; 182; 27,26; 173,7; dan 1.411 ppm. Hasil identifikasi golongan senyawa aktif dengan uji reagen dan KLTA menunjukkan bahwa ekstrak Chlorella $s p$. mengandung steroid dan asam askorbat. Eluen yang baik untuk KLT steroid adalah n-heksana:aseton (7:3) dan n-heksana:etil asetat (7:3). Eluen terbaik untuk KLT asam askorbat adalah etanol p.a.:asam asetat 10\% (9:1).

Kata kunci: Chlorella sp., Hidrolisis, Antioksidan, DPPH, KLT

\section{PENDAHULUAN}

Firman Allah Swt. surat Luqman ayat 10 menjelaskan bahwa Allah telah menciptakan berbagai macam binatang dan tumbuh-tumbuhan yang dapat dimanfaatkan oleh manusia dalam berbagai keperluan. ${ }^{1}$ Salah satunya adalah mikroalga jenis Chlorella sp..
Chlorella sp. merupakan tumbuhan ganggang hijau bersel tunggal yang tumbuh dapat di air tawar, air payau, dan air asin. Berdasarkan cara pembudidayaan, Chlorella sp. memiliki beberapa keunggulan diantaranya berkembang biak dengan cepat, mudah dalam membudidayakannya $^{2}$ karena hidupnya 
tidak tergantung musim, tidak memerlukan tempat yang luas dan tidak memerlukan waktu yang lama untuk memanennya ${ }^{3}$.

Pembudidayaan Chlorella sp. dapat dilakukan dengan cara kultivasi dalam Medium Ekstrak Tauge (MET). MET ini merupakan salah satu media alami untuk pertumbuhan mikroalga. MET mengandung nutrient organik seperti karbohidrat, protein, vitamin dan lemak yang dibutuhkan sebagai sumber energi bagi pertumbuhan mikroalga. MET juga memberikan pertumbuhan yang pesat terhadap mikroalga dibandingkan pada MAL (Medium Air Laut) dan MG (Medium Guillard). ${ }^{4}$

Chlorella sp. yang telah dibudidayakan dapat dimanfaatkan di berbagai keperluan diantaranya sebagai sumber energi alternatif, pangan sehat dan suplemen. Chlorella sp. mengandung berbagai nutrien seperti protein, karbohidrat, asam lemak tak jenuh, vitamin, klorofil, enzim, dan serat yang tinggi. ${ }^{5}$ Chlorella sp. juga mengandung klorofil $a$, klorofil $b$, serta karotenoid. Klorofil dan karotenoid ini dapat berfungsi sebagai antioksidan.

Antioksidan memiliki peranan penting dalam mencegah oksidasi radikal bebas yang dapat menyebabkan berbagai penyakit seperti karsinogenik dan penuaan. ${ }^{6}$ Saat ini antioksidan yang umum digunakan merupakan antioksidan sintetik diantaranya Butylated hydroxyanisole (BHA), Butylated hydroxytoluene (BHT), Propylgallate (PG) dan Tert-Butylhydroquinone (TBHQ). ${ }^{7}$ Akan tetapi, senyawa tersebut dicurigai dapat menyebabkan keracunan dan efek karsinogenik. ${ }^{8,9,10}$ Oleh karena itu, pengembangan serta pemanfaatan antioksidan alami yang lebih efektif penting untuk dilakukan. ${ }^{11}$

Senyawa antioksidan dalam Chlorella sp. kebanyakan berasal dari senyawa-senyawa metabolit sekunder yang dihasilkan pada fase stationer. Fase stasioner pada kurva pertumbuhan Chlorella sp. yaitu hari ke-10 memiliki bioaktivitas tertinggi dibandingkan dengan fase lainnya. ${ }^{12}$
Ekstrak metanol Chlorella sp. mempunyai nilai $\mathrm{EC}_{50}$ yang kecil yaitu $18,610 \mathrm{ppm}^{13}$ menunjukkan bahwa Chlorella sp. berpotensi sebagai antioksidan. Senyawa-senyawa antioksidan yang terkandung dalam mikroalga Chlorella sp. umumnya merupakan senyawa metabolit sekunder. Metabolit sekunder ini kebanyakan di alam berupa glikosida. Penelitian aktivitas antioksidan terhadap mikroalga Eucheuma spinosum dengan metode DPPH dengan parameter $\mathrm{EC}_{50}$ menunjukkan bahwa aktivitas antioksidan ekstrak yang telah dihidrolisis adalah lebih besar dibandingkan sebelum dihidrolisis. ${ }^{14}$

\section{METODOLOGI}

\section{Lokasi dan Waktu Penelitian}

Penelitian ini dilaksanakan di Laboratorium Kimia Organik, Laboratorium Bioteknologi Jurusan Kimia dan Laboratorium Fisiologi Tumbuhan Jurusan Biologi Universitas Islam Negeri (UIN) Maulana Malik Ibrahim Malang pada bulan November 2013 - April 2014.

\section{Alat}

Seperangkat alat gelas, autoklaf, inkubator, neraca analitik, cawan porselen, desikator, shaker, rotary evaporator vacuum, kuvet, aluminium foil, sentrifuse, spektofotometer UV-Vis Varian Carry, dan spektronik $20+$.

\section{Bahan}

Isolat mikroalga Chlorella sp. dari Laboratorium Fisiologi Tumbuhan jurusan Biologi UIN Maulana Malik Ibrahim Malang. Bahan-bahan lain yang digunakan adalah metanol p.a, etil asetat p.a, kloroform p.a, petroleum eter, n-heksana p.a, tauge (kacang hijau), akuades, larutan DPPH 0,2 mM, HCl $2 \mathrm{~N}$, anhidrida asetat, asam sulfat pekat, serbuk $\mathrm{Mg}, \mathrm{HCl} 37 \%$, $\mathrm{HCl} 2 \%$, etanol $95 \%$, etanol $99 \%$, natrium karbonat, reagen Dragendorff, reagen Mayer, reagen Limberman-Burchard, vitamin $\mathrm{C}$, dan BHT. 


\section{Metode Penelitian}

\section{A. Kultivasi Mikroalga Chlorella sp. 1. Sterilisasi Alat}

Alat-alat yang akan disterilkan ditutup dengan alumunium foil. Kemudian dimasukkan ke dalam autoklaf dan diatur pada suhu $121{ }^{\circ} \mathrm{C}$ dengan tekanan 15 psi (per square inchi) selama 15 menit. ${ }^{15}$

\section{Pembuatan Medium Ekstrak Tauge}

Pembuatan medium ekstrak tauge diawali dengan pembuatan larutan stok MET yaitu 100 gram tauge direbus dalam $500 \mathrm{~mL}$ akuades yang mendidih selama 1 jam hingga volume ekstrak $200 \mathrm{~mL}$. Medium ekstrak tauge $4 \%(\mathrm{v} / \mathrm{v})$ sebanyak $600 \mathrm{~mL}$ dibuat dengan cara melarutkan 24 $\mathrm{mL}$ ekstrak tauge ke dalam akuades $576 \mathrm{~mL}$ dalam erlenmeyer $1000 \mathrm{~mL}$, tanpa perlakuan $\mathrm{pH} .{ }^{16}$

\section{Kultivasi Chlorella sp. dalam Media Ekstrak Tauge}

Sebanyak $100 \mathrm{ml}$ isolat Chlorella sp. diinokulasikan ke dalam masing-masing $600 \mathrm{~mL}$ MET dalam erlenmeyer $1000 \mathrm{~mL}$ yang ditempatkan pada rak yang telah dilengkapi dengan pencahayaan menggunakan lampu TL 36 watt (intensitas cahaya $1000-4000$ lux) dan fotoperiodisitas 14 jam terang dan 10 jam gelap selama 10 hari. $^{16}$

\section{B. Pemanenan Biomassa Chlorella sp.}

Media kultur Chlorella sp. disentrifugasi selama 15 menit dengan kecepatan 3000 rpm. Biomassa Chlorella $s p$. dipisahkan dari supernatannya.

\section{Preparasi Sampel}

Sampel biomassa Chlorella sp. diambil seluruhnya kemudian dikeringanginkan pada suhu ruang, $25-30{ }^{\circ} \mathrm{C}$ selama 48 jam.

\section{Penentuan Kadar Air}

Cawan yang akan digunakan dipanaskan dahulu dalam oven suhu 100$105{ }^{\circ} \mathrm{C}$ selama 15 menit, kemudian cawan disimpan dalam desikator 10 menit, ditimbang dan dilakukan perlakuan yang sama hingga diperoleh berat cawan yang konstan. Biomassa Chlorella sp. ditimbang $1 \mathrm{mg}$ kemudian dimasukkan ke dalam cawan dan dikeringkan di dalam oven suhu $100-105{ }^{\circ} \mathrm{C}$ selama 30 menit, kemudian dimasukkan dalam desikator, ditimbang dan dilakukan perlakuan yang sama hingga diperoleh berat cawan yang konstan. Kadar air dihitung menggunakan rumus:

$$
\begin{aligned}
\text { Kadar air }= & \frac{(\mathrm{b}-\mathrm{c})}{\mathrm{b}-\mathrm{a}} \times 100 \% \\
\text { Dimana: } \mathrm{a}= & \text { bobot cawan kosong } \\
\mathrm{b}= & \text { bobot sampel }+ \text { cawan sebelum } \\
& \text { dipanaskan } \\
\mathrm{c}= & \text { bobot cawan }+ \text { sampel setelah } \\
& \text { dipanaskan }
\end{aligned}
$$

\section{E. Ekstraksi Senyawa Aktif Mikroalga Chlorella sp.}

Biomassa Chlorella sp. kering 50 gram dimaserasi dengan pelarut metanol p.a 250 $\mathrm{mL}$ selama 24 jam dan dishaker selama 5 jam. Maserasi dilakukan tiga kali. Setelah itu dipisahkan antara filtrat dengan residu. Filtrat yang diperoleh dipekatkan dengan rotary evaporator vacuum dan dialiri gas $\mathrm{N}_{2}$ hingga diperoleh ekstrak pekat metanol, kemudian dihitung rendemennya dengan rumus:

Rendemen $=\frac{\text { Berat ekstrak kasar yang diperoleh }}{\text { Berat sampel yang digunakan }} \times 100 \%$

\section{F. Hidrolisis dan Partisi Ekstrak Pekat Metanol Mikroalga Chlorella sp.}

Ekstrak pekat metanol sebanyak 1 gram dihidrolisis dengan katalis $\mathrm{HCl} 2 \mathrm{~N}$ sebanyak $2 \mathrm{~mL}$ dan distirrer selama 1 jam dengan hot plate stirrer. Selanjutnya ditambahkan natrium bikarbonat hingga pH-nya netral. Kemudian dipartisi secara bertingkat dengan pelarut n-heksana, petroleum eter, kloroform, dan etil asetat. Masing-masing fraksi pelarut (hasil partisi) dipekatkan dengan rotary evaporator dan dialiri gas $\mathrm{N}_{2}$. Selanjutnya dihitung rendemennya dengan rumus:

Rendemen $=\frac{\text { Berat ekstrak kasar yang diperoleh }}{\text { Berat sampel yang digunakan }} \times 100 \%$ 


\section{G. Uji Aktivitas Antioksidan dengan DPPH (1,1-diphenyl-2-picrylhydrazyl) \\ 1. Penentuan Panjang Gelombang Maksimum}

Etanol $95 \%$ dipipet sebanyak 6,75 mL kemudian ditambahkan larutan DPPH 0,2 mM sebanyak 2,25 mL, dimasukkan ke dalam tabung reaksi kemudian dimasukkan ke dalam kuvet hingga penuh. Selanjutnya dicari $\lambda_{\text {maks }}$ larutan dan dicatat hasil pengukuran $\lambda_{\text {maks }}$ untuk digunakan pada tahap selanjutnya. ${ }^{17}$

\section{Penentuan Waktu Kestabilan Pengukuran Antioksidan}

Larutan tiap fraksi $30 \mathrm{ppm}$ dipipet sebanyak $6,75 \mathrm{~mL}$ dan ditambahkan larutan DPPH 0,2 $\mathrm{mM}$ sebanyak 2,25 $\mathrm{mL}$. Kemudian waktu kestabilan dicari tanpa inkubasi dan setelah inkubasi pada suhu 37 ${ }^{\circ} \mathrm{C}$ dan rentangan waktu 5-100 menit dengan interval 5 menit. Sampel diukur menggunakan spektronik $20+$ pada $\lambda_{\text {maks }}$ yang telah diketahui pada tahap sebelumnya. $^{13}$

\section{Pengukuran Potensi Antioksidan Pada Sampel}

Sampel ekstrak dilarutkan dalam etanol $95 \%$ dengan konsentrasi 5, 10, 15, 20, 25, dan 30 ppm. Ekstrak masing-masing konsentrasi dipipet $6,75 \mathrm{~mL}$ dan ditambahkan 2,25 $\mathrm{mL}$ DPPH $0,2 \mathrm{mM}$ kemudian diinkubasi dengan suhu $37{ }^{\circ} \mathrm{C}$ pada waktu kestabilan yang diperoleh pada tahap sebelumnya, kemudian diukur absorbansinya menggunakan spektrofotometer UV-Vis pada panjang gelombang 518,0 nm. Data absorbansinya yang diperoleh dari tiap konsentrasi masing-masing ekstrak dihitung nilai persen $(\%)$ aktivitas antioksidannya: ${ }^{18}$

$$
\underset{\text { antioksidan }}{\text { Aktivitas }}=\left(\frac{\text { A kontrol-A sampel }}{\text { A kontrol }}\right) \times 100 \%
$$

Kontrol yang digunakan yaitu Larutan DPPH 0,2 mM sebanyak 2,25 mL dalam 6,75 $\mathrm{mL}$ etanol $95 \%$. Pembanding BHT dan asam askorbat (Vitamin C) diperlakukan seperti sampel.

\section{H. Identifikasi Golongan Senyawa Aktif Secara Kualitatif dengan Reagen \\ 1. Uji Terpenoid dan Steroid}

Ekstrak kasar diambil dan dilarutkan dengan kloroform sebanyak $0,5 \mathrm{~mL}$, lalu ditambah dengan $0,5 \mathrm{~mL}$ anhidrida asetat. Selanjutnya ditambah dengan $1-2 \mathrm{~mL}$ $\mathrm{H}_{2} \mathrm{SO}_{4}$ pekat melalui dinding tabung tersebut. Warna hijau kebiruan menunjukkan adanya steroid, jika berupa cincin kecoklatan atau violet pada perbatasan dua pelarut menunjukkan adanya triterpenoid. ${ }^{19}$

\section{Uji Flavonoid}

Ekstrak dilarutkan dalam $1-2 \mathrm{~mL}$ metanol panas $50 \%$, kemudian ditambah logam $\mathrm{Mg}$ dan 0,5 mL HCl pekat. Senyawa flavonoid akan menimbulkan warna merah atau jingga. ${ }^{20}$

\section{Uji Alkaloid}

Ekstrak kasar ditambah $0,5 \mathrm{~mL} \mathrm{HCl} 2$ $\%$, selanjutnya larutan dibagi dalam dua tabung. Tabung I ditambahkan $2-3$ tetes reagen Dragendorff, tabung II ditambahkan $2-3$ tetes reagen Mayer. Jika tabung I terbentuk endapan jingga dan pada tabung II terbentuk endapan kekuning-kuningan menunjukkan adanya alkaloid. ${ }^{20}$

\section{Uji Asam Askorbat}

Masing-masing ekstrak dilarutkan dalam akuades kemudian ditambahkan larutan $\mathrm{KMnO}_{4}$ 0,1 \%. Jika terbentuk warna cokelat maka menunjukkan adanya asam askorbat. $^{2113}$

\section{Uji Senyawa Aktif dengan KLTA}

Uji senyawa aktif dengan KLT dilakukan terhadap golongan senyawa yang positif dari hasil uji senyawa aktif dengan uji reagen dan memiliki nilai $\mathrm{EC}_{50}$ paling rendah. Identifikasi dengan KLT digunakan plat silika gel $\mathrm{F}_{254}$ yang sudah diaktifkan dengan pemanasan dalam oven pada suhu 60-80 ${ }^{\circ} \mathrm{C}$ selama 30 menit. Masing-masing plat dengan ukuran $1 \times 10 \mathrm{~cm}^{2}$. Ekstrak Chlorella $s p$. ditotolkan pada jarak $\pm 1 \mathrm{~cm}$ dari tepi bawah plat dengan pipa kapiler. Noda/bercak hasil pemisahan kemudian diamati di bawah sinar UV pada panjang gelombang $254 \mathrm{~nm}$ dan $366 \mathrm{~nm}$. 
KLTA untuk golongan senyawa steroid menggunakan eluen nheksana:aseton (7:3), ${ }^{22} \mathrm{n}$-heksana:etil asetat $(9: 1),{ }^{23}$ n-heksana:etil asetat $(8: 2),{ }^{24} \mathrm{n}$ heksana:etil asetat (6:4), ${ }^{24}$ n-heksana:etil asetat (7:3), ${ }^{25}$ dengan pereaksi Lieberman Buchard dideteksi di bawah lampu UV 366 nm. KLTA asam askorbat menggunakan eluen etanol : asam asetat $10 \%(9: 1),{ }^{20}$ etanol : asam asetat glasial (9:1), etanol:asam asetat $1 \%(9: 1),{ }^{26}$ etanol : asam asetat glasial : toluen $(5,5: 1: 1,5),{ }^{27}$ etil asetat : asam asetat glasial : asam format : air $(6: 1: 1: 2),{ }^{28}$ dilihat dibawah lampu UV $254 \mathrm{~nm}$ menghasilkan spot biru gelaphitam. Tetapi sebagai perbandingan, hasil elusi juga dideteksi di bawah lampu UV $366 \mathrm{~nm}$.

\section{J. Analisis Data}

Analisis data dilakukan dengan menghitung persen (\%) aktivitas antioksidan dari data absorbansi masingmasing ekstrak dan pembanding asam askorbat (vitamin C) dan BHT. Nilai EC $_{50}$ dihitung dengan menggunakan software "GraphPad prism6 software" dengan persamaan regresi non linear "Regression for analyzing dose-response data" yang menyatakan hubungan antara log konsentrasi ekstrak (x) dengan persen (\%) aktivitas antioksidan (y). ${ }^{13}$ Semakin kecil nilai $\mathrm{EC}_{50}$ maka semakin tinggi kemampuan ekstrak sebagai antioksidan.

\section{HASIL DAN PEMBAHASAN}

\section{A. Kultivasi Mikroalga Chlorella sp.}

Kultivasi Chlorella sp. dilakukan dalam Medium Ekstrak Tauge (MET). MET mengandung unsur makro dan mikro, vitamin, mineral serta asam amino yang dibutuhkan bagi pertumbuhan mikroalga Chlorella sp.. Unsur hara yang terkandung dalam MET seperti K, P, Ca, Mg, Fe, Na, $\mathrm{Zn}, \mathrm{Mn}$, dan $\mathrm{Cu}$ sedangkan vitamin yang terkandung dalam media tersebut diantaranya karoten, thiamin, riboflavin, niasin, dan vitamin $\mathrm{C}^{29}$

Chlorella sp. dikultivasi dalam MET $4 \%$ selama 10 hari. Pencahayaan menggunakan lampu TL (Tube Lamp) sebagai pengganti sinar matahari dengan fotoperiodisitas 14 jam terang dan $10 \mathrm{jam}$ gelap yang bertujuan untuk mengatur pencahayaan dalam fotosintesis.

Temperatur selama kultivasi Chlorella sp. adalah temperatur ruang (25$30{ }^{\circ} \mathrm{C}$ ). Rostini (2007) ${ }^{30}$ menumbuhkan Chlorella sp. menggunakan medium air laut dengan temperatur berkisar antara $20-27$ ${ }^{\circ} \mathrm{C}$.

Penelitian ini menggunakan MET 4 $\%$ tanpa perlakuan $\mathrm{pH}(\mathrm{pH} \pm 7)$. Kisaran $\mathrm{pH}$ yang sesuai untuk pertumbuhan mikroalga yaitu $4,5-9,3 .^{16}$

Selama masa kultivasi terjadi perubahan warna kultur yang semula berwarna hijau kekuningan menjadi hijau tua hingga pada hari ke-10 kultivasi. Gradasi warna hijau selain menunjukkan peningkatan populasi sel Chlorella sp., juga mengindikasikan peningkatan kadar klorofil yang merupakan pigmen utama yang terdapat dalam sitoplasma sel.

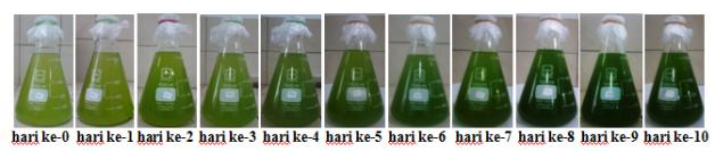

Gambar 1 Warna kultur Chlorella sp. pada hari berbeda

\section{B. Pemanenan Mikroalga Chlorella sp.}

Pemanenan biomassa Chlorella $s p$. dilakukan pada hari ke-10 yang merupakan fase stasioner dari fase pertumbuhan Chlorella sp.. Kurva pertumbuhan mikroalga Chlorella sp. menunjukkan bahwa fase stasioner hari ke-10 kepadatan sel Chlorella $s p$. berada dalam jumlah sel tertinggi, yaitu $4.880 .000 \mathrm{sel} / \mathrm{mL}$ dengan aktivitas antibakteri yang tertinggi dibandingkan dengan fase lainnya. ${ }^{12}$

Pada fase stasioner terjadi metabolisme sekunder yang merupakan keseluruhan proses sintesis dan perombakan produk metabolit primer. ${ }^{31}$ Contoh produk senyawa metabolit sekunder seperti senyawa fenol, alkaloid, triterpenoid. ${ }^{32}$ 


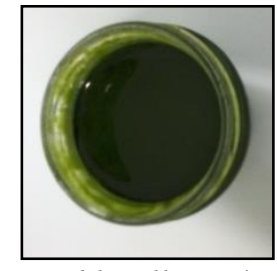

Gambar 2 Biomassa Chlorella sp. hasil pemanenan

\section{Preparasi Sampel}

Preparasi sampel biomassa Chlorella $s p$. dilakukan dengan pengeringanginan selama 48 jam menggunakan kipas angin. Pengeringanginan dengan kipas angin tidak menimbulkan panas dan dapat membawa uap air yang lebih besar daripada pengeringan $\mathrm{AC}$ dan blowerheat, sehingga proses pengeringan berlangsung lebih cepat sebelum terjadinya kerusakan bahan. ${ }^{33}$ Hasil yang diperoleh dari proses pengeringan adalah 12,0423 gram biomassa kering dari total 423,2000 gram biomassa basah dan rendemennya $2,8455 \%$.

\section{Analisis Kadar Air}

Penentuan kadar air dilakukan untuk mengetahui kadar air yang terkandung dalam sampel. Semakin rendah nilai kadar air bahan maka akan semakin memudahkan pelarut untuk mengekstrak komponen senyawa aktif yang diinginkan. Maksimum kadar air yang disyaratkan agar proses ekstraksi dapat berjalan lancar yaitu sebesar $11 \% .^{34}$ Kadar air dari biomassa kering Chlorella sp. adalah 7,8099\%.

\section{E. Ekstraksi Senyawa Aktif Mikroalga Chlorella sp.}

Ekstraksi Chlorella sp. dilakukan dengan metode maserasi menggunakan pelarut metanol p.a. Hasil rendemen ekstraksi maserasi ditunjukkan pada Tabel 2 .

Tabel 2 Rendemen Ekstraksi Chlorella sp.

\begin{tabular}{cccc}
\hline $\begin{array}{c}\text { Biomassa } \\
(\text { gram })\end{array}$ & $\begin{array}{c}\text { Ekstrak } \\
(\text { gram })\end{array}$ & $\begin{array}{c}\text { Rendemen } \\
(\boldsymbol{\%})(\mathbf{b} / \mathbf{b})\end{array}$ & $\begin{array}{c}\text { Warna } \\
\text { Ekstrak } \\
\text { Pekat }\end{array}$ \\
\hline 10,0001 & 1,3607 & 13,6069 & $\begin{array}{c}\text { Hijau tua } \\
\text { pekat }\end{array}$ \\
\hline
\end{tabular}

\section{F. Hidrolisis dan Partisi Ekstrak Pekat Metanol Mikroalga Chlorella sp.}

Senyawa-senyawa antioksidan yang terkandung dalam mikroalga Chlorella $s p$. umumnya merupakan senyawa metabolit sekunder. Metabolit sekunder kebanyakan di alam berupa glikosida (mengandung komponen gula dan bukan gula). Pemutusan ikatan glikosida dapat dilakukan dengan reaksi hidrolisis menggunakan katalis asam.

Ekstrak pekat metanol Chlorella $s p$. dihidrolisis dengan katalis $\mathrm{HCl} 2 \mathrm{~N}$ untuk mempercepat pemutusan ikatan glikosida antara senyawa glikon dan aglikon. Asam kuat lebih mudah melepas ion $\mathrm{H}^{+}$secara sempurna didalam air. Konsentrasi ion $\mathrm{H}^{+}$ inilah yang mempengaruhi kecepatan reaksi pemutusan ikatan glikosida. $\mathrm{HCl}$ menghasilkan garam $(\mathrm{NaCl})$ pada penetralan yang tidak menimbulkan gangguan. Penetralan hidrolisat $\mathrm{NaHCO}_{3}$ bertujuan menghentikan reaksi hidrolisis yang reversible (dapat balik). Jika reaksi tidak dihentikan maka akan terbentuk kembali ikatan glikosida antara glikon dan aglikon. ${ }^{35}$

Proses partisi dilakukan secara bertingkat yaitu dengan pelarut n-heksana, petroleum eter, kloroform dan etil asetat. Proses partisi dengan pelarut yang berbeda kepolaran ini dimaksudkan agar senyawasenyawa yang memiliki kepolaran yang berbeda dapat terekstrak ke dalam pelarut yang sesuai.

Pada saat proses partisi terbentuk 2 lapisan yang tidak saling bercampur yaitu lapisan fasa air yang bersifat polar dan lapisan fasa organik yang bersifat semi polar atau nonpolar. Fasa air mengekstrak komponen gula (glikon) sedangkan fasa organik mengekstrak metabolit sekunder (aglikon). Hasil rendemen masing-masing fraksi terlihat pada Tabel 3. 
Tabel 3 Rendemen masing-masing fraksi hasil partisi

\begin{tabular}{lcc}
\hline \multicolumn{1}{c}{ Fraksi } & $\begin{array}{c}\text { Warna ekstrak } \\
\text { pekat }\end{array}$ & $\begin{array}{c}\text { Rendemen } \\
(\mathbf{\%})(\mathbf{b} / \mathbf{b})\end{array}$ \\
\hline n-Heksana & Hijau kehitaman & 45,6132 \\
Petroleum & Hijau kehitaman & 8,1854 \\
eter & & \\
Kloroform & Hijau kecoklatan & 7,5573 \\
Etil asetat & Hijau & 7,4377 \\
Air & Hijau & 10,0897 \\
\hline
\end{tabular}

Pelarut n-heksana memiliki hasil rendemen tertinggi yaitu sebesar 45,6132 $\%$. Hasil memberikan informasi bahwa sebagian besar senyawa pada ekstrak metanol Chlorella sp. yang telah dihidrolisis memiliki kepolaran sesuai dengan kepolaran n-heksana (non polar).

G. Uji Aktivitas Antioksidan dengan DPPH (1,1-diphenyl-2-picrylhydrazyl)

\section{Penentuan Panjang Gelombang} Maksimum

Hasil penentuan panjang gelombang DPPH $0,2 \quad \mathrm{mM}$ diperoleh panjang gelombang maksimum sebesar 518,0 nm.

\section{Penentuan Waktu Kestabilan \\ Pengukuran Antioksidan}

Pengukuran waktu kestabilan penting dilakukan karena untuk mengetahui waktu sampel dan DPPH sudah bereaksi secara stabil yang ditunjukkan dengan tidak adanya lagi penurunan absorbansi. Setiap senyawa memiliki waktu kestabilan yang berbeda untuk dapat bereaksi secara sempurna. ${ }^{36}$

Penentuan waktu kestabilan pada ekstrak metanol, hasil partisi fraksi nheksana, petroleum eter, kloroform, etil asetat, fasa air, serta pembanding BHT dan vitamin $\mathrm{C}$ dilakukan tanpa inkubasi dan dengan inkubasi pada suhu $37^{\circ} \mathrm{C}$ selama 5 - 100 menit (atau sampai diperoleh batas atas waktu kestabilannya) dengan interval 5 menit. Hasil penentuan waktu kestabilan masing-masing ekstrak terhadap DPPH menggunakan inkubasi pada suhu $37{ }^{\circ} \mathrm{C}$ dan tanpa inkubasi disajikan pada Tabel 4.

Hasil penentuan waktu kestabilan masing-masing ekstrak waktu kestabilan yang lebih cepat dicapai dan nilai absorbansi yang lebih stabil dibandingkan tanpa inkubasi. Sampel dengan menunjukkan bahwa sampel yang ditambahkan DPPH dengan inkubasi pada suhu $37{ }^{\circ} \mathrm{C}$ memiliki inkubasi cenderung lebih stabil dan memiliki penurunan nilai absorbansi yang lebih rendah dibandingkan tanpa inkubasi.

Tabel 4 Waktu kestabilan masing-masing ekstrak

\begin{tabular}{lcc}
\hline \multirow{2}{*}{ Sampel } & \multicolumn{2}{c}{ Waktu kestabilan } \\
\cline { 2 - 3 } & $\begin{array}{c}\text { dengan } \\
\text { inkubasi } \\
\text { (menit) }\end{array}$ & $\begin{array}{c}\text { tanpa inkubasi } \\
\text { (menit) }\end{array}$ \\
\hline Vitamin C & $25-50$ & $40-65$ \\
BHT & $35-75$ & $65-90$ \\
Metanol & $15-65$ & $60-95$ \\
n-Heksana & $45-90$ & $55-85$ \\
Petroleum & $55-85$ & $65-95$ \\
Eter & & \\
Kloroform & $55-90$ & $75-105$ \\
Etil Asetat & $60-90$ & $85-120$ \\
Fasa Air & $55-95$ & $75-120$ \\
\hline
\end{tabular}

3. Pengukuran Potensi Antioksidan pada Mikroalga Chlorella sp.

Uji kuantitatif potensi antioksidan pada ekstrak Chlorella sp. dilakukan dengan uji DPPH secara spekrofotometri sinar tampak. Metode ini didasarkan pada perubahan warna radikal DPPH dari ungu menjadi kuning yang disebabkan oleh reaksi antara radikal bebas DPPH dengan satu atom hidrogen yang dilepaskan senyawa yang terkandung dalam bahan uji untuk membentuk senyawa 1,1-diphenyl-2picrylhydrazin yang berwarna kuning. Pada metode ini absorbansi yang diukur adalah absorbansi larutan DPPH sisa yang tidak bereaksi dengan senyawa antioksidan. ${ }^{38}$

Pengujian potensi antioksidan dilakukan pada semua fraksi ekstrak Chlorella sp. dan pembanding yaitu BHT dan vitamin $\mathrm{C}$ (asam askorbat). Pengukuran potensi antioksidan dari masing-masing sampel dilakukan dengan variasi konsentrasi 5, 10, 15, 20, 25, dan 30 ppm, diinkubasi sesuai waktu kestabilan yang telah didapatkan pada masing-masing ekstrak dan diukur serapannya pada panjang gelombang 518,0 $\mathrm{nm}$. 
Parameter yang digunakan untuk mengetahui potensi antioksidan dalam ekstrak Chlorella $s p$. yaitu persen (\%) aktivitas antioksidan dan nilai $\mathrm{EC}_{50}$. Persen aktivitas antioksidan (\%) menunjukkan banyaknya atom hidrogen dari senyawa antioksidan yang menangkap radikal DPPH sehingga tereduksi menjadi DPPH-H $(1,1$ diphenyl-2-picrylhydrazyn). ${ }^{39}$ Data hasil \% aktivitas antioksidan ditunjukkan pada Tabel 5.

Tabel 5 Persen aktivitas antioksidan dan nilai $\mathrm{EC}_{50}$ ekstrak Chlorella sp. dan pembanding

\begin{tabular}{clrrrrrr}
\hline \multirow{2}{*}{ No. Sampel } & \multicolumn{6}{c}{ \% aktivitas antioksidan } \\
& & $\mathbf{5} \mathbf{~ p p m}$ & $\mathbf{1 0} \mathbf{~ p p m}$ & $\mathbf{1 5} \mathbf{~ p p m}$ & $\mathbf{2 0} \mathbf{~ p p m}$ & $\mathbf{2 5} \mathbf{~ p p m}$ & \multicolumn{1}{c}{$\mathbf{3 0} \mathbf{~ p p m}$} \\
\hline 1. & Ekstrak Metanol & 0,6098 & 0,6646 & 0,8864 & 1,2065 & 1,8387 & 2,0957 \\
2. & Ekstrak n-Heksana & 0,1480 & 0,4425 & 0,4901 & 0,5234 & 0,6388 & 1,7564 \\
3. & Ekstrak Petroleum eter & 0,7068 & 1,8652 & 2,5287 & 7,8273 & 37,6118 & $\mathbf{6 4 , 8 8 3 9}$ \\
4. & Ekstrak Kloroform & 0,8342 & 0,8476 & 4,8666 & 5,3512 & 7,9819 & 8,0472 \\
5. & Ekstrak Etil asetat & 0,8618 & 4,6571 & 4,7180 & 5,7809 & 7,1768 & 9,4496 \\
6. & Fasa Air & 0,9902 & 1,2737 & 1,6327 & 1,7731 & 2,5699 & 3,4392 \\
7. & Asam askorbat & 71,2814 & 76,0809 & 94,4278 & 94,8744 & 95,4452 & 95,9923 \\
8. & BHT & 9,9193 & 20,6979 & 34,0538 & 38,1616 & 40,1994 & 51,1178 \\
\hline
\end{tabular}

Ekstrak fraksi petroleum eter Chlorella sp. pada konsentrasi $30 \mathrm{ppm}$ memiliki persen (\%) aktivitas antioksidan yang paling besar dibandingkan ekstrak Chlorella sp. lainnya. Persen aktivitas antioksidan ekstrak fraksi petroleum eter pada konsentrasi $30 \mathrm{ppm}$ lebih tinggi dibandingkan pembanding BHT tetapi lebih kecil dibandingkan dengan vitamin $\mathrm{C}$ (pada konsentrasi $30 \mathrm{ppm}$ ). Semakin besar persen aktivitas antioksidannya maka semakin besar kemampuan ekstrak dalam meredam radikal DPPH.

Parameter $\quad \mathrm{EC}_{50} \quad$ (effective concentration) didefinisikan sebagai

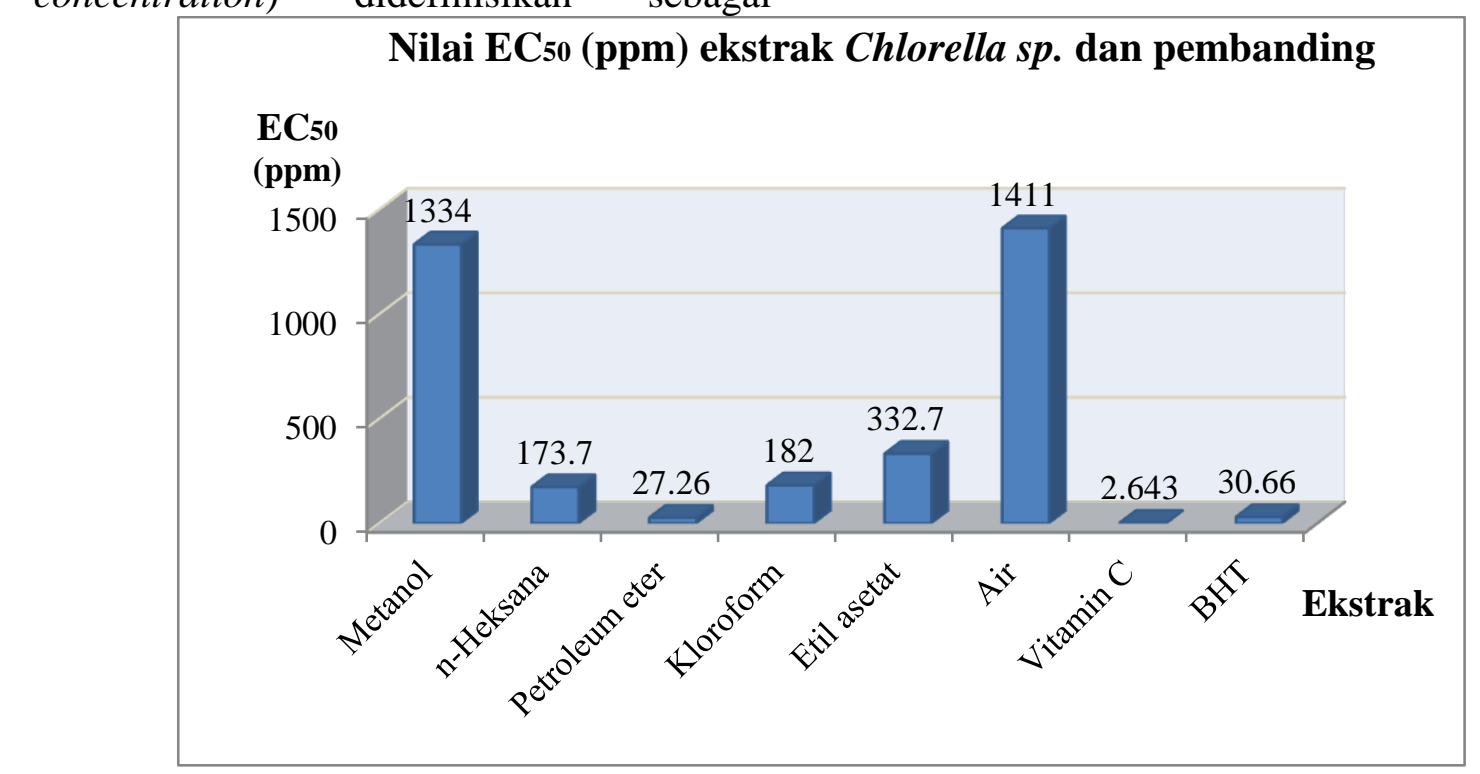

Gambar 4 Nilai $\mathrm{EC}_{50}$ ekstrak Chlorella sp. dan pembanding konsentrasi larutan sampel yang akan menyebabkan reduksi terhadap aktivitas DPPH sebesar $50 \%$. Semakin kecil nilai $\mathrm{EC}_{50}$ maka aktivitas antioksidannya semakin tinggi. ${ }^{40}$ Nilai $\mathrm{EC}_{50}$ diperoleh dengan mengolah data persen aktivitas antioksidan dan dianalisis menggunakan persamaan regresi non linear dengan menggunakan "GraphPad prism6 software, Regression for analyzing dose-response data". Data hasil nilai $\mathrm{EC}_{50}$ ditunjukkan pada Gambar 4. 
Ekstrak petroleum eter memiliki nilai $\mathrm{EC}_{50}$ terkecil diantara masing-masing ekstrak Chlorella sp.. Nilai $\mathrm{EC}_{50}$ ekstrak petroleum eter adalah 27,26 ppm artinya dengan penambahan antioksidan dari ekstrak sebanyak 27,26 ppm larutan uji akan menangkap radikal bebas sebanyak $50 \%$ dari total radikal bebas. Hasil ini juga menunjukkan bahwa ekstrak Chlorella $s p$. setelah dihidrolisis dan dipartisi dengan petroleum eter memiliki potensi antioksidan yang lebih kuat dibandingkan dengan ekstrak sebelum dihidrolisis (ekstrak metanol). Hal ini terlihat dari nilai $\mathrm{EC}_{50}$ ekstrak petroleum eter lebih kecil dibandingkan dengan $\mathrm{EC}_{50}$ ekstrak metanol. Semakin kecil $\mathrm{EC}_{50}$ suatu senyawa uji maka senyawa tersebut semakin efektif sebagai penangkal radikal bebas. ${ }^{41}$

\section{H. Uji Fitokimia Ekstrak Chlorella sp. dengan Reagen}

Uji fitokimia dilakukan untuk mengetahui kandungan senyawa aktif pada bahan uji secara kualitatif. Uji fitokimia pada penelitian ini dilakukan terhadap ekstrak Chlorella $s p$. yang meliputi ekstrak metanol, fraksi n-heksana, petroleum eter, kloroform, etil asetat dan fasa air. Hasil uji fitokimia mikroalga Chlorella $s p$. ditunjukkan dalam Tabel 6.

Tabel 6 Hasil Uji Fitokimia Ekstrak Mikroalga Chlorella sp.

\begin{tabular}{|c|c|c|c|c|c|c|c|}
\hline \multirow[b]{2}{*}{ No. } & \multirow[b]{2}{*}{$\begin{array}{l}\text { Golongan } \\
\text { Senyawa }\end{array}$} & \multicolumn{6}{|c|}{ Hasil Pengujian Tiap Ekstrak } \\
\hline & & Metanol & n-Heksana & $\begin{array}{c}\text { Petroleum } \\
\text { eter }\end{array}$ & Kloroform & $\begin{array}{c}\text { Etil } \\
\text { asetat }\end{array}$ & Air \\
\hline 1. & Alkaloid & - & - & - & - & - & - \\
\hline 2. & Flavonoid & - & - & - & - & - & - \\
\hline 3. & Steroid & + & + & + & + & + & + \\
\hline 4. & Terpenoid & - & - & - & - & - & - \\
\hline 5. & Asam askorbat & + & + & + & + & + & + \\
\hline & Keterangan & & tor & $\begin{array}{l}\text { /warn } \\
\text { tyawa/ }\end{array}$ & la & & \\
\hline
\end{tabular}

\section{Steroid}

Identifikasi adanya golongan senyawa steroid pada ekstrak Chlorella $s p$. menggunakan reaksi Liebermann-Burchard (anhidrida asetat- $\mathrm{H}_{2} \mathrm{SO}_{4}$ pekat). Steroid akan mengalami dehidrasi akan menghasilkan produk oksidasi yang memberikan reaksi warna hijau kebiruan.

Semua ekstrak Chlorella sp. memberikan warna hijau kebiruan pada uji golongan senyawa steroid yang menunjukkan bahwa ekstrak tersebut mengandung golongan senyawa steroid. Senyawa steroid cenderung bersifat non polar atau semi polar, namun dapat terekstrak dalam pelarut metanol yang bersifat polar. Hal ini diduga karena steroid masih terikat pada glikosidanya sehingga ikut terekstrak dalam pelarut metanol yang bersifat polar. Beberapa senyawaan steroid mengandung gugus $-\mathrm{OH}$ yang sering disebut dengan sterol, sehingga sifatnya cenderung lebih polar. ${ }^{42}$

\section{Asam Askorbat}

Asam askorbat positif terkandung dalam ekstrak Chlorella sp. yaitu adanya perubahan warna dari pereduksi kalium permanganat yang semula berwarna ungu berubah menjadi cokelat.

\section{Pemisahan Senyawa Aktif dengan KLTA}

KLTA digunakan untuk mengetahui eluen terbaik dalam memisahkan senyawa. KLTA dilakukan terhadap ekstrak yang menghasilkan nilai $\mathrm{EC}_{50}$ terkecil yaitu ekstrak petroleum eter Chlorella sp. yang positif mengandung steroid dan asam askorbat.

\section{KLTA Steroid}

Hasil elusi KLTA senyawa golongan steroid ditampilkan pada Tabel 7 . Berdasarkan 5 variasi eluen tersebut, terdapat dua macam campuran eluen yang 
menunjukkan hasil pemisahan baik yaitu

dan n-heksana : etil asetat (7:3).

KLT dengan eluen heksana : aseton (7:3)

Tabel 7 Data penampakan noda senyawa steroid dari hasil KLTA fraksi petroleum eter Chlorella sp. dengan lampu UV $366 \mathrm{~nm}$

\begin{tabular}{|c|c|c|c|}
\hline No. & Fase Gerak & $\begin{array}{c}\text { Jumlah noda dengan pendeteksi } \\
\text { Lieberman-Buchard }\end{array}$ & Nilai Rf \\
\hline 1. & $\begin{array}{c}\text { heksana:aseton } \\
(7: 3)\end{array}$ & 13 & $\begin{array}{l}0,03 ; 0,06 ; 0,13 ; 0,21 ; 0,31 ; 0,36 ; 0,5 \\
0,69 ; 0,79 ; 0,84 ; 0,93 ; 0,96 ; 0,99\end{array}$ \\
\hline 2. & $\begin{array}{l}\text { heksana:etil } \\
\text { asetat }(9: 1)\end{array}$ & 6 & 0,$04 ; 0,08 ; 0,1 ; 0,14 ; 0,44 ; 0,65$ \\
\hline 3. & $\begin{array}{l}\text { heksana:etil } \\
\text { asetat }(8: 2)\end{array}$ & 8 & $\begin{array}{l}0,03 ; 0,05 ; 0,09 ; 0,15 ; 0,51 ; 0,55 ; 0,59 ; \\
0,77\end{array}$ \\
\hline 4. & $\begin{array}{l}\text { heksana:etil } \\
\text { asetat }(6: 4)\end{array}$ & 3 & 0,$03 ; 01375 ; 1$ \\
\hline 5. & $\begin{array}{l}\text { heksana:etil } \\
\text { asetat }(7: 3)\end{array}$ & 12 & $\begin{array}{l}0,03 ; 0,13 ; 0,25 ; 0,46 ; 0,53 ; 0,58 ; 0,73 ; \\
0,74 ; 0,79 ; 0,85 ; 0,93 ; 0,96\end{array}$ \\
\hline
\end{tabular}
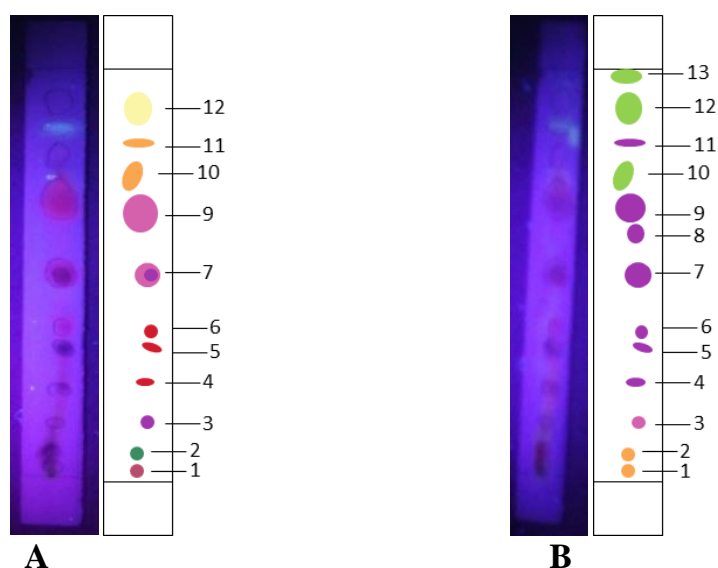

Gambar 5 Hasil KLT senyawa steroid pada fraksi petroleum eter Chlorella sp. pada eluen n-heksana:aseton (7:3) dideteksi dibawah lampu UV $366 \mathrm{~nm}$ (a) hasil elusi sebelum disemprot reagen LiebermanBurchard (b) hasil elusi setelah disemprot reagen Lieberman-Burchard

Tabel 8 Hasil KLT senyawa steroid pada fraksi petroleum eter Chlorella sp. pada eluen n-heksana:aseton (7:3) dideteksi di bawah lampu UV $366 \mathrm{~nm}$

\begin{tabular}{ccccc}
\hline No. & $\begin{array}{c}\text { Rf } \\
\text { tiap } \\
\text { noda }\end{array}$ & $\begin{array}{c}\text { Warna noda di bawah sinar UV pada } \boldsymbol{\lambda} \mathbf{3 6 6} \mathbf{~ n m} \\
\text { Sebelum disemprot reagen } \\
\text { Liebermann-Buchard }\end{array}$ & $\begin{array}{c}\text { Setelah disemprot reagen } \\
\text { Liebermann-Buchard }\end{array}$ & $\begin{array}{c}\text { Dugaan } \\
\text { senyawa }\end{array}$ \\
\hline 1 & 0,03 & Merah muda & Orange & - \\
2 & 0,06 & Hijau & Orange & - \\
3 & 0,13 & Ungu & Merah muda & Steroid \\
4 & 0,21 & Merah & Ungu & Steroid \\
5 & 0,31 & Merah & Ungu & Steroid \\
6 & 0,36 & Merah & Ungu & Steroid \\
7 & 0,50 & Merah muda-ungu & Ungu & Steroid \\
8 & 0,69 & - & Ungu & Steroid \\
9 & 0,79 & Merah muda-ungu & Ungu & Steroid \\
10 & 0,84 & Orange & Hijau & Steroid \\
11 & 0,93 & Orange & Ungu & Steroid \\
12 & 0,96 & Kuning & Hijau & Steroid \\
13 & 0,99 & - & Hijau & Steroid \\
\hline
\end{tabular}


Hasil identifikasi dengan KLT golongan senyawa steroid dalam fraksi petroleum eter Chlorella $s p$. dengan eluen n-heksana : aseton (7:3) menghasilkan pemisahan yang baik karena dihasilkan 13 spot atau noda jelas dan tidak terjadi tailing. Pemisahan dikatakan baik apabila menghasilkan komponen senyawa berupa noda yang banyak, noda yang terbentuk bulat tidak berekor, dan pemisahan nodanya jelas. ${ }^{43}$

Noda yang berhasil dipisahkan memiliki rentang nilai $\mathrm{Rf}$ antara $0,03-0,99$ dengan noda 1 dan 2 berwarna orange, noda 3 berwarna merah muda, noda 4-9 dan noda 11 berwana ungu, kemudian noda 10 , 12, 13 berwarna hijau. Pada hasil KLT ini yang diduga senyawa golongan steroid adalah noda dengan merah muda, ungu ${ }^{23}$ dan hijau ${ }^{44}$ setelah disemprot reagen Liebermann-Burchard dan dideteksi di bawah lampu UV $366 \mathrm{~nm}$.

Hasil pemisahan senyawa golongan steroid pada fraksi petroleum eter Chlorella $s p$. dengan eluen n-heksana : etil asetat (7:3). Hasil elusi dapat ditunjukkan pada Gambar 6. dengan rincian keterangan warna dan nilai Rf ditampilkan pada Tabel 9.

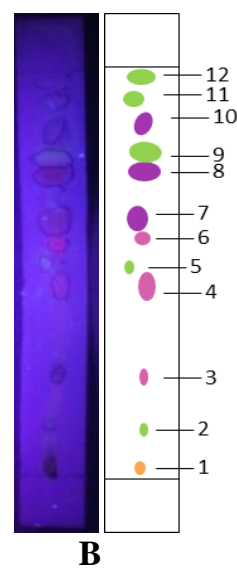

Gambar 6 Hasil KLT senyawa steroid pada fraksi petroleum eter Chlorella sp. pada eluen n-heksana:etil asetat (7:3) dideteksi dibawah lampu UV $366 \mathrm{~nm}$ (a) hasil elusi sebelum disemprot reagen LiebermanBurchard (b) hasil elusi setelah disemprot reagen Lieberman-Burchard

Tabel 9 Hasil KLT senyawa steroid pada fraksi petroleum eter Chlorella sp. pada eluen n-heksana:etil asetat (7:3) dideteksi di bawah lampu UV $366 \mathrm{~nm}$

\begin{tabular}{ccccc}
\hline No. & $\begin{array}{c}\text { Rf } \\
\text { tiap } \\
\text { noda }\end{array}$ & $\begin{array}{c}\text { Sebelum disemprot reagen } \\
\text { Liebermann-Buchard }\end{array}$ & $\begin{array}{c}\text { Warna noda diah disemprot reagen } \\
\text { Liebermann-Buchard }\end{array}$ & $\begin{array}{c}\text { Dugaan } \\
\text { senyawa }\end{array}$ \\
\hline 1 & 0,03 & Orange & Orange & - \\
2 & 0,13 & Ungu & Hijau & Steroid \\
3 & 0,25 & Ungu & Merah muda & Steroid \\
4 & 0,46 & Merah muda & Merah muda & Steroid \\
5 & 0,53 & - & Hijau & Steroid \\
6 & 0,58 & Merah muda & Merah muda & Steroid \\
7 & 0,63 & Merah muda & Ungu & Steroid \\
8 & 0,74 & Merah muda & Ungu & Steroid \\
9 & 0,79 & Hijau & Hijau & Steroid \\
10 & 0,85 & Hijau & Ungu & Steroid \\
11 & 0,93 & Orange & Hijau & Steroid \\
12 & 0,96 & - & Hijau & Steroid \\
\hline
\end{tabular}

Hasil KLT golongan senyawa steroid dengan eluen n-heksana:etil asetat (7:3) menghasilkan pemisahan yang baik karena dihasilkan 12 spot atau noda jelas dan tidak 
terjadi tailing. Noda yang berhasil dipisahkan memiliki rentang nilai $\mathrm{Rf}$ antara 0,03-0,96 dengan noda 1 berwarna orange; noda 3, 4, 6 berwarna merah muda; noda 2 , 5, 9, 11, 12 berwarna hijau; dan noda 7, 8, 10 berwana ungu. Noda yang diduga senyawa golongan steroid adalah noda dengan warna merah muda, ungu dan hijau. Hasil pemisahan dengan eluen n-heksana : aseton (7:3) dengan rentang $\operatorname{Rf} 0,13-0,99$ dan n-heksana : etil asetat (7:3) dengan $\mathrm{Rf}$ 0,13-0,96 memiliki hasil warna yang sama untuk noda yang diduga senyawa steroid yaitu warna merah muda, hijau dan ungu.

\section{KLTA Asam Askorbat}

Senyawa yang juga positif terdeteksi dalam fraksi petroleum eter Chlorella $s p$. adalah asam askorbat. Hasil KLTA asam askorbat menunjukkan eluen dengan pemisahan terbaik adalah eluen etanol : asam asetat $10 \%(9: 1),{ }^{20}$ Hasil elusi dari tiap eluen ditunjukkan pada Tabel 10.

Tabel 10 Data penampakan noda senyawa asam askorbat dari hasil KLTA fraksi petroleum eter Chlorella sp. dengan lampu UV $254 \mathrm{~nm}$ dan $366 \mathrm{~nm}$

\begin{tabular}{|c|c|c|c|c|c|}
\hline \multirow{2}{*}{ No. } & \multirow{2}{*}{ Fase Gerak } & \multicolumn{2}{|c|}{ Pada 254 nm } & \multicolumn{2}{|r|}{ Pada 366 nm } \\
\hline & & Noda & $\mathbf{R f}$ & Noda & $\mathbf{R f}$ \\
\hline 1. & Etanol:asam asetat $10 \%(9: 1)$ & 2 & 0,$80 ; 0,91$ & 4 & 0,$80 ; 0,86 ; 0,89 ; 0,91$ \\
\hline 2. & Etanol:asam asetat glasial $(9: 1)$ & 1 & 0,94 & 2 & 0,$91 ; 0,96$ \\
\hline 3. & Etanol:asam asetat $1 \%(9: 1)$ & 2 & 0,$79 ; 0,89$ & 3 & 0,$79 ; 0,84 ; 089$ \\
\hline 4. & $\begin{array}{l}\text { Etanol:asam asetat glasial:toluen } \\
\qquad(5,5: 1: 1,5)\end{array}$ & 1 & 0,96 & 1 & 0,96 \\
\hline 5. & $\begin{array}{c}\text { Etil asetat:asam asetat } \\
\text { glasial:asam format:air }(6: 1: 1: 2)\end{array}$ & 1 & 0,94 & 1 & 0,95 \\
\hline
\end{tabular}

Hasil KLT dari pemisahan asam askorbat fraksi petroleum eter Chlorella $s p$. dengan eluen etanol:asam asetat $10 \% \quad(9: 1)$

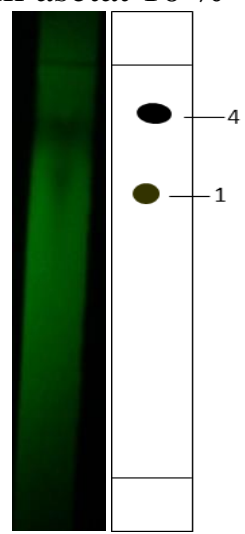

A ditunjukkan pada Gambar 7. dengan rincian keterangan warna dan nilai $\mathrm{Rf}$ ditampilkan pada Tabel 11.

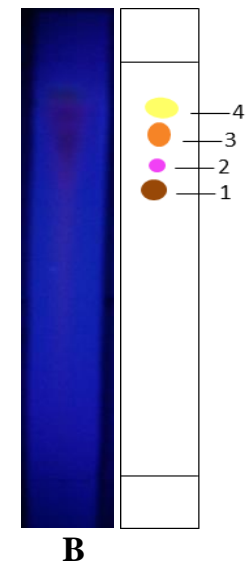

Gambar 7 Hasil KLT asam askorbat pada fraksi petroleum eter Chlorella sp. pada eluen etanol:asam asetat 10 $\%$ (9:1) (a) hasil elusi dideteksi dengan lampu UV $254 \mathrm{~nm}$ (b) hasil elusi dideteksi dengan lampu UV $366 \mathrm{~nm}$

Tabel 11 Hasil KLT asam askorbat pada fraksi petroleum eter Chlorella sp. dengan eluen etanol:asam asetat 10

\begin{tabular}{ccccc}
\multicolumn{7}{c}{$\%$} & $(9: 1)$ & & \\
\hline No & Rf & Warna noda pada $254 \mathbf{~ n m}$ & Warna noda pada 366 nm & Dugaan senyawa \\
\hline 1 & 0,80 & Coklat-hitam & Orange-coklat & - \\
2 & 0,86 & - & Merah muda-ungu & - \\
3 & 0,89 & - & Orange & - \\
4 & 0,91 & Hitam & kuning & Asam askorbat \\
\hline
\end{tabular}


Hasil KLT asam asskorbat dengan eluen etanol:asam asetat $10 \% \quad(9: 1)$ terdeteksi 2 spot berwarna coklat hitam dan hitam pada panjang gelombang $254 \mathrm{~nm}$ dan 4 spot pada $366 \mathrm{~nm}$ dengan warna orange kecoklatan, merah muda-ungu, orange dan kuning. Noda yang diduga senyawa asam askorbat adalah noda 4 dengan $\operatorname{Rf} 0,91$ karena dilihat dibawah lampu UV pada panjang gelombang $254 \mathrm{~nm}$ menghasilkan spot biru gelap. Asam askorbat yang bersifat polar lebih terdistribusi ke fasa geraknya (etanol:asam asetat $10 \%(9: 1)$ ) yang bersifat lebih polar dari pada plat KLT sehingga memiliki Rf yang besar yaitu 0,91 .

\section{PENUTUP}

\section{Kesimpulan}

Nilai $\mathrm{EC}_{50}$ dari fraksi etil asetat, kloroform, petroleum eter, n-heksana, air dan ekstrak metanol berturut-turut yaitu $332 ; 182 ; 27,26 ; 173,7 ; 1.411$; dan 1.334

\section{DAFTAR PUSTAKA}

${ }^{1}$ Shihab, M.Q. 2002. Tafsir Al Mishbah : pesan, kesan dan keserasian Al Quran. Jakarta : Lentera Hati.

${ }^{2}$ Sidabutar, E.A.. 1999. Pengaruh Medium Pertumbuhan Mikroalga Chlorella $s p$. terhadap Aktivitas Senyawa Pemacu Pertumbuhan yang Dihasilkan. Skripsi Tidak Diterbitkan. Institut Pertanian Bogor.

${ }^{3}$ Borowitzka, M. A. dan Lesley, J. B. 1988. Microalgae Biotechnology. London: Cambridge University Press.

${ }^{4}$ Wulandari, A.P., Frida N., Annisa E.P., dan Dilaekha R.P.. 2010. Identifikasi Mikroalgae di Sekitar Pantai Pangandaran dan Potensi Pertumbuhannya pada Formulasi Medium Ekstrak Tauge (MET). Prosiding Seminar Nasional Limnologi, V.

${ }^{5}$ Kawaroe, M. 2008. Mikroalga sebagai Bahan Baku Biofuel. Surfactant and Bioenergy Research Centre, Lembaga Pengabdian Pada ppm. Fraksi petroleum eter Chlorella sp. memiliki aktivitas antioksidan yang paling tinggi karena mempunyai nilai $\mathrm{EC}_{50}$ paling kecil.

Ekstrak mikroalga Chlorella sp. mengandung senyawa steroid dan asam askorbat. Hasil KLTA fraksi petroleum eter mikroalga Chlorella sp. menunjukkan bahwa eluen yang baik untuk pemisahan golongan senyawa steroid adalah heksana:aseton (7:3) dan n-heksana:etil asetat (7:3). Eluen terbaik dalam pemisahan asam askorbat adalah etanol:asam asetat 10 $\%(9: 1)$.

\section{Saran}

Penelitian ini dapat dilanjutkan dengan KLTP untuk pemisahan senyawa yang berpotensi sebagai antioksidan. Kemudian dapat dilanjutkan dengan identifikasi dengan menggunakan LC-MS.

Masyarakat, Institut Pertanian Bogor.

${ }^{6}$ Yan, X., Nagata, T., and Xiao, F.. 1998. Antioxidative Activities in Some Common Seaweeds. Journal of Plant Foods for Human Nutrition Institute of Oceanology,LII.

${ }^{7}$ Sherwin, F.R., 1990. Antioxidant. In: Food Additive (ed. Branen R). New York: Marcel Dekker.

${ }^{8}$ Grillo, C.A. and F.N. Dulout. 1995. Cytogenetic Evaluation of Butylated Hydroxytoluene. Mutat. Res., (345) : 73-85.

${ }^{9}$ Safer, A.M. dan A.L. Nughamish. 1999. Hepatotoxicity Induced by the Antioxidant Food Additive Butylated Hydroxytoluene (BHT) in Rats: An Electron Microscopical Study. Histol. Histopathol., XIV: 391-406.

${ }^{10}$ Shanab, S.M.M.. 2007. Antioxidant and Antibiotic Activities of Some Seaweeds (Egyptian Isolates). Agriculture and Biology, IX (2): 220-225. 
${ }^{11}$ Oktay, M., I. Gulcin, and O., Kufrevioglu, 2003. Determination of In Vitro Antioxidant Activity of Fennel (Foeniculum Vulgare) Seed Extract. Lebensmittel-Wissenchaft and Technology, XXXVI: 263-271.

${ }^{12}$ Khamidah, U. 2013. Uji Aktivitas Antibakteri Ekstrak Metanol Mikroalga Chlorella sp. Hasil Kultivasi dalam Medium Ekstrak Tauge Terhadap Escherichia coli dan Staphylococcus aureus. Skripsi Tidak Diterbitkan. Malang : Universitas Islam Negeri Maulana Malik Ibrahim Malang.

${ }^{13}$ Bariyyah, S.K. 2013. Uji Aktivitas Antioksidan Terhadap DPPH dan Identifikasi Golongan Senyawa Aktif Ekstrak Kasar Mikroalga Chlorella sp. Hasil Kultivasi dalam Medium Ekstrak Tauge. Skripsi Tidak Diterbitkan. Malang : Jurusan Kimia Fakultas Sains dan Teknologi Universitas Islam Negeri Maulana Malik Ibrahim Malang.

${ }^{14}$ Mardiyah, U. 2012. Ekstraksi Uji Aktivitas Antioksidan Terhadap DPPH dan Identifikasi Golongan Senyawa Aktif Alga Merah Eucheuma spinosum dari Perairan Banyuwangi. Skripsi Tidak Diterbitkan. Malang: Universitas Islam Negeri Maulana Malik Ibrahim Malang.

${ }^{15}$ Hidayati, Nurul. 2009. Uji Efektivitas Antibakteri Ekstrak Kasar Daun The (Camellia sinensis L, v. assamica) Tua Hasil Ekstraksi Menggunakan Pelarut Akuades dan Etanol. Skripsi Tidak Diterbitkan. Malang: Universitas Islam Negeri Maulana Malik Ibrahim Malang.

${ }^{16}$ Prihantini, N.H, Putri B., dan Yuliati R.. 2005. Pertumbuhan Chlorella sp. dalam Medium Ekstrak Tauge (MET) dengan Variasi $\mathrm{pH}$ Awal. Makara, Sains, IX (1): 1-6.
${ }^{17}$ Hanani, E., M. Abdul dan Ryany, S. 2005. Identifikasi Senyawa Antioksidan dalam Spons Callyspongia sp. dari Kepulauan Seribu. Majalah Ilmu Kefarmasian, II (3): 127-133.

${ }^{18}$ Arindah, D. 2010. Fraksinasi dan Identifikasi Golongan Senyawa Antioksidan pada Daging Buah Pepino (Solonum Muricatum aiton) yang Berpotensi sebagai Antioksidan. Skripsi Tidak Diterbitkan. Malang: Jurusan Kimia Fakultas Sains dan Teknologi Universitas Islam Negeri (UIN) Maulana Malik Ibrahim Malang.

${ }^{19}$ Harborne, J.B. 1996. Metode Fitokimia Penuntun Cara Modern Menganalisis Tumbuhan. Bandung : Penerbit ITB.

${ }^{20}$ Indrayani, L., Soetjipto, H., dan Sihasale, L. 2006. Skrining Fitokimia dan Uji Toksisitas Ekstrak Daun Pecut Kuda (Stachytarpheta jamaicensis L. Vahl) terhadap Larva Udang Artemia salina Leach. Berk. Penelitian. Hayati, Vol. XII: 57-61.

${ }^{21}$ Auterhoff, H. dan Kovar, K.A. 1987. Identifikasi Obat, Terbitan Kelima. Terjemahan N.C. Sugiarso. Bandung: Penerbit ITB.

${ }^{22}$ Syamsudin., Tjokrosonto, S., Wahyuono, S dan Mustofa. 2007. Aktivitas Antiplsmodium dari dua Fraksi Ekstrak n-Heksana Kulit Batang Asam Kandis (Garcinia parvifolia Miq). Majalah Farmasi. Yogyakarta: Universitas Gajah Mada.

${ }^{23}$ Sulastry, T dan Kurniawati, N. 2010. Isolasi Steroid dari Ekstrak Metanol daun Bluntas (Plucea indica L). Jurnal Chemica Vol. II. FMIPA UNM.

${ }^{24}$ Reveny, J. 2007. Daya Antimikroba Ekstrak dan Fraksi Daun Sirih Merah (Piper betle L.). Fakultas Farmasi Universitas Sumatra Utara. Jurnal Ilmu Dasar .Vol.12 No.1: 612. 
${ }^{25}$ Hayati, K., Jannah, A., Ningsih R. 2012. Identifikasi Senyawa dan Aktivitas Antimalaria In Vivo Ekstrak Etil Asetat Tanaman Anting-Anting (Acalypha Indica L.). Molekul. Vol 7 No 1. Malang : Jurusan Kimia UIN Maulana Malik Ibrahim Malang.

${ }^{26}$ Himesh, S., Singhai, A.K., dan Sarvesh S. 2012. Quantification of Ascorbic Acid in Leaves of Annona squamosa. International Journal of Pharmacy and Pharaceutical Sciences. ISSN. 0975-1491 Vol.4.Prihantini, N.H, Putri B., dan Yuliati R.. 2005. Pertumbuhan Chlorella sp. dalam Medium Ekstrak Tauge (MET) dengan Variasi pH Awal. Makara, Sains, IX (1): 1-6.

${ }^{27}$ Kondawar, M.S., Kamble, K.G., dan Mali, D.S. 2011. Quantitative estimation of Gallic acid in a Marketed Herbal Medicine: Triphala Churna by High Perfomance Thin Layer Chromatography. International Journal of Pharm Tech Research. ISSN : 0974-4303. Vol. 3., No. 3.

${ }^{28}$ Patel, N.V., dan Telange, D.R. 2011. Qualitative and Quantitative Estimation of Gallic Acid and Ascorbic Acid in Polyherbal Tablet. International Journal of Pharaceutical Sciences and Reasearch. ISSN: 0975-8232. Vol. 2. India : School of Pharmacy and Technology Management.

${ }^{29}$ Persagi (Persatuan Ahli Gizi Indonesia). 2009. Tabel Komposisi Pangan Indonesia. Jakarta: PT. Elex Media Komputindo.

${ }^{30}$ Rostini, I.. 2007. Kultur Fitoplankton (Chlorella sp. dan Tetraselmis chuii) pada Skala Laboratorium. Karya Ilmiah. UNPAD.

${ }^{31}$ Herbert RB. 1995. Biosintesis Metabolit Sekunder. Bambang Srigandono, penerjemah. Edisi kedua. Semarang: IKIP Semarang Press.

${ }^{32}$ Yudha, A.P.. 2008. Senyawa Antibakteri dari Mikroalga Dunaliella sp. pada Umur Panen yang Berbeda. Skripsi Tidak Diterbitkan. Bogor : Fakultas Perikanan dan Ilmu Kelautan, Institut Pertanian Bogor.

${ }^{33}$ Mohammad, J. 2007. Produksi dan Karakterisasi Biopigmen Fikosianin dari Spirulina fusiformis serta Aplikasinya sebagai Pewarna Minuman. Thesis Tidak Diterbitkan. Bogor: Program Studi Teknologi Hasil Pertanian Institut Pertanian Bogor.

${ }^{34}$ Nurmillah, Ovi, Y. 2009. Kajian Aktivitas Antioksidan dan Antimikroba Ekstrak Biji, Kulit Buah, Batang dan Daun Tanaman Jarak Pagar (Jatropha curcas L.). Skripsi diterbitkan. Bogor: Fakultas Teknologi Pertanian IPB.

${ }^{35}$ Handoko, D.S.P. 2006. Kinetika Hidrolisis Maltosa pada Variasi Suhu dan Jenis Asam sebagai Katalis. Jurnal. Jember: Jurusan Kimia FMIPA Universitas Jember. SIGMA.Vol.9 No.1 ISSN 1410-5888.

${ }^{36}$ Brand-Williams, W. 1995. Use of Free Radical Method to Evaluate Antioxidant activity. Lebensmettel Wissenschaft and Technologie. Dalam Ratmo. 2007. Potensi Ekstrak Daun Sirih Merah (Piper crocotum) sebagai Antioksidan. www.kimiabrawijaya.ac.id.

${ }^{37}$ Suroso, H.C. 2011. Uji Antioksidan dan Identifikasi Senyawa Aktif pada Tanaman Anting-anting (Achalypha Indica L.). Skripsi Tidak Diterbitkan. Malang: Jurusan Kimia Fakultas Sains dan Teknologi Universitas Islam Negeri Maaulana Malik Ibrahim Malang.

${ }^{38}$ Josephy, P.D. 1997. Molecular Toxicology. New York: Oxford University Press. 
${ }^{39}$ Rahayu, D.S., Dewi, K., Enny, F. 2010. Penentuan Aktivitas Antioksidan dari Ekstrak Etanol Daun Ketapang (Terminalia catappa L) dengan Metode 1,1 difenil 2 Pikrilhidrazil $(D P P H) . \quad$ Skripsi Diterbitkan. Semarang: Jurusan Kimia FMIPA Universitas Diponegoro.

${ }^{40}$ Molyneux, P.. 2003. The Use of The Stable Free Radical Diphenylpicrylhydrazyl (DPPH), for Estimating Antioxidant Activity. Science and Technology, Vol. 26. No. 2: 211-219.

${ }^{41}$ Rohman, A., Riyanto. 2005. Aktivitas Antioksidan Ekstrak Buah Mengkudu (Morinda Citrifolia L,). Agritech, Vol. 25. No. 3: 131-136.

${ }^{42}$ Sriwahyuni, I. 2010. Uji Fitokimia Ekstrak Tanaman Anting-Anting (Acalypha Indica Linn) Dengan Variasi Pelarut Dan Uji Toksisitas Menggunakan Brine Shrimp (Artemia Salina Leach). Skripsi Tidak Diterbitkan. Malang: Jurusan Kimia Fakultas Sains dan Teknologi, UIN Malang.

${ }^{43}$ Gandjar, I.B., dan Rohman, A. 2007. Kimia Farmasi Analisis.

Yogyakarta: Pustaka Pelajar.

${ }^{44}$ Handayani D., N. Sayuti dan Dachriyanus. 2008. Isolasi dan Karakterisasi Senyawa Antibakteri Epidioksi Sterol dari Spon Laut Petrosia nigrans, Asal Sumatera Barat. Prosiding Seminar Nasional Sains dan Teknologi- II 2008. Lampung: Universitas Lampung. 